\title{
Factors Affecting the Use of Information for Academic Library Decision Making
}

\section{Charles R. McClure and Alan R. Samuels}

This paper reports on a study of academic librarians' perceptions of information processing and organizational climate. After providing a brief review of related research and literature on the topic, the paper discusses findings that include a significant relationship between the climate dimension of democratic governance and information dissemination; a high dependency of academic librarians on internal oral sources as input for decision making; and the minimal selection of information resources based on clientele information or empirical research as input for decision making. The paper concludes by suggesting that decision making is likely to be "short-circuited" in the academic libraries investigated and offers some recommendations for how information can be better exploited for increased decision-making effectiveness.

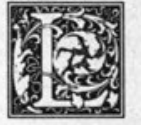

ibrary management has been studied primarily within the context of academic libraries. In addition to the contextual limitation of library management studies, there appears to be a substantial selfimposed restriction on what is studied. The more concrete manifestations of library management, such as resource allocation, receive more attention than the psychological and less easily measured aspects-a logical and consistent development of scientific management that has so pervaded library administrative history. ${ }^{1}$ Factors related to how members affect, and are affected by, the function and activities of their particular library have not received adequate research attention.

Probably the single most important cause of perceptual differences between groups of workers within a library as well as between librarians and clients is the use of information for decision making. This is essentially a communication problem. If communication cannot be carried out in an effective way, then information trans- mission is likely to be distorted. Porter and Roberts emphasize this problem by suggesting that little is known about (1) how information comes into an organization, (2) how it is used, and (3) what differentiates between internally and externally generated information. ${ }^{2}$

Many other scholars from a variety of disciplines have stressed the vital importance of information in affecting peoples' behavior, particularly cognitive studies and interpersonal communication; ${ }^{3}$ information for decision making and the role of the information rich in decision making ${ }^{4}$ the influence and "power" of information in organizations; ${ }^{5}$ and the management of information resources in organizations. ${ }^{6}$ These authors, and others, have directly or indirectly pointed out that the effective organization is one that places emphasis on acquiring, processing, and distributing information in the most utilitarian way possible.

However, there is likely to be no consistent pattern in the processing and use of information across organizations because

Charles R. McClure is professor in the School of Library and Information Studies at the University of Oklahoma, Norman, Oklahoma 73019. Alan R. Samuels is assistant professor in the School of Library and Information Science at the University of Missouri, Columbia, Missouri 65211. 
of differences in organizational characteristics ${ }^{7}$ and the resistance between various groups in society caused by conflicting cultures unique to specific organizations. As a result, methods of organizational information acquisition, dissemination, and evaluation take on particular importance in such communication and information dependent agencies as libraries.

One measure that is particularly helpful in analyzing organizations is organizational climate. A review of research dealing with organizational climate has been given by Samuels, ${ }^{9}$ Samuels and McClure, ${ }^{10}$ and Soudek, ${ }^{11}$ and will not be repeated here. In general, organizational climate is a relatively enduring quality of the internal environment of an organization that (a) is experienced by its members, (b) influences their behavior, and (c) can be described in terms of values held by organizational members of a particular set of characteristics (or attributes) of the organization. ${ }^{12}$

Although in recent years the concept has undergone some revision, notably by Guion, ${ }^{13}$ its basic conceptual underpinnings have remained unchanged: organizational climate is a psychologically based method of describing how peoples' value systems coexist with those of the organization. Climate measures have been used to study "open" and "closed" organizations, ${ }^{14}$ leadership styles and motivation, ${ }^{15}$ managerial styles, ${ }^{16}$ and occasionally, though very rarely, libraries. ${ }^{17}$

Change requires climates that are receptive to innovation, allow the accurate diagnosis of problems and development of strategies to deal with these problems. ${ }^{18}$ However, before such climates can be created it is necessary to take a "snapshot" of what the organization looks like before, not after, change activity takes place. This process can greatly assist in the organizational development of libraries by providing baseline data that describe the current climate conditions.

For example, "open" climates tend to be receptive to growth, change, and innovation adoption. Such climates encourage individual self-actualization and emphasize integration and accomplishment of organizational and individual goals. "Closed" climates tend to be strongly committed to maintaining the status quo, limit the ability of individuals to develop new skills, and minimize the necessity of developing short- and middle-range strategies to respond to changing environmental conditions. The study of organizational information processing, decision making, and climate is important to librarians seeking to adequately plan for what appear to be substantial changes in assessing the library's role in society.

For example, information management has become an increasingly important administrative strategy. Unfortunately, libraries have failed to develop systems for information management such as management information systems (MIS) or Decision Support Systems (DSS). ${ }^{19}$ Reasons for this are not hard to find. First, librarians' focus on information itself typically is user oriented rather than decision oriented. Secondly, the scientific management basis of most library administration precludes broad participation in the decisionmaking process. Yet, how, why, and to what purpose information is used in libraries is rightly the concern of all librarians as a means of improving overall organizational effectiveness.

As used in this paper, decision making refers to any act of conscious choice in which the decision maker's value system serves to assign meaning to certain data. These data then become stimuli that impel the decision maker to pursue various courses of action. These actions are assumed likely to lead to the accomplishment of certain desired objectives. ${ }^{20}$ Thus, "information" broadly describes anything that aids the cognitive ability of a decision maker to select among a number of competing alternatives. As resources dwindle and programs multiply, decision making takes on increasing importance.

\section{STUDY OBJECTIVES}

Bundy remains a primary source for describing how decisions are made in libraries. ${ }^{11}$ Her groundbreaking discussion emphasized the need to analyze decisionmaking processes in order to manage libraries successfully. The literature which supports Bundy's view, most of it from nonlibrary contexts, is substantial and 
easily available elsewhere. An excellent account of this literature base, especially from a cognitive viewpoint, is given by Janis \& Mann. ${ }^{22}$

Although attempts have been made to study library decision-making processes, ${ }^{23}$ we still have little understanding of the complex forces that cause academic librarians to use information for decision making. This seems in direct conflict with the interest among administrators in formalized planning processes.

The study of information use in library decision making takes on great importance when the isolation of library decision making from information research is considered. In spite of enormous efforts to implement complex mechanisms and provide services requiring very rich information environments, suggestions on how to use information in the decision making and planning processes are rarely considered.

Thus, a purpose of this study is to investigate factors that affect the use of information for academic library decision making, more specifically:

- Why are specific types of information sources selected for specific types of library decisions?

- Are library organizational information acquisition and dissemination related to organizational climates?

- What organizational factors tend to prevent optimal uses of information for library decision making?

Exploratory investigation of these and related research questions may assist both researchers and library administrators to design library organizations that can better exploit information as input for library decision making and planning.

\section{RESEARCH DESIGN}

Results reported in this paper deal with the academic library portion of a larger study that investigated information processing, decision making, and organizational climate in both academic and public libraries. Data collection began in late fall 1979 , and was completed during $1980 .^{24}$

A random sample of medium-sized to moderately large academic libraries was selected using the $32 \mathrm{~d}$ (1979) edition of the
American Library Directory as a source. A pool of potential academic library participants was selected by the researchers; each library met minimum criteria of 150,000 volumes, ten professional FTE librarians, and represented the four geographic areas of the United States as defined by the U.S. Bureau of Census (West, South, Midwest, and Northeast). The directors of these libraries were contacted by letter and asked if their professional staff would participate in the project by completing questionnaires. For purposes of data analysis, the investigators determined that a minimum of sixteen academic libraries (four per geographic region) would be acceptable.

Interest in participating in the study was received from twenty-four academic libraries. A packet of questionnaires was sent to each director (or library liaison) who then distributed them to the professional staff.* Librarians then completed the questionnaires and returned them directly to the investigators. After one reminder notice was distributed to all study participants, it was determined that two of the twenty-four libraries had changed their mind about participating in the study and four of the libraries failed to produce a minimum response rate of 60 percent. Therefore, these six libraries were dropped from further participation in the study. Overall, the eighteen academic libraries that participated in the study had a response rate of 76 percent and no individual library had less than a 60 percent response rate.

\section{Study Participants}

Table 1 summarizes selected institutional characteristics of the academic libraries in the sample, and table 2 provides an overview of respondents' characteristics across these libraries.

In general, participating academic libraries gravitated toward the higher end of the scale in terms of budget, but re-

\footnotetext{
*The length of the questionnaire precludes its reprinting. Additional information about the questionnaire may be obtained from the authors.
} 
TABLE 1

ACADEMIC LIBRARY SUMMARY CHARACTERISTICS $(\mathrm{N}=18)^{*}$

\begin{tabular}{lrr}
\hline \hline Characteristic & \multicolumn{1}{c}{ Average } & \multicolumn{1}{c}{ Range } \\
\hline 1. Professional staff size & 26 & $10-56$ \\
2. Total staff size (FTE) & 92 & $23-260$ \\
3. Number of volumes & 676,028 & $181,000-2,083,329$ \\
4. Annual budget & $\$ 1,818,914$ & $\$ 669,319-\$ 5,400,000$ \\
\hline
\end{tabular}

*Based on statistics as reported in American Library Directory, 32d. ed. (New York: R. R. Bowker, 1980) and data supplied by participating libraries.

TABLE 2

ACADEMIC LIBRARY RESPONDENT CHARACTERISTICS

A. Experience in participating library and total professional experience.

\begin{tabular}{|c|c|c|c|}
\hline \multirow{2}{*}{\multicolumn{2}{|c|}{$\begin{array}{l}\text { Length of Employment Time } \\
\text { as Professional in Respondent's } \\
\text { Library (in Years) } \\
\text { Number of }\end{array}$}} & \multicolumn{2}{|c|}{$\begin{array}{l}\text { Total Professional } \\
\text { Experience (in Years) }\end{array}$} \\
\hline & & $\begin{array}{c}\text { Number of } \\
\text { Years }\end{array}$ & $\begin{array}{c}\% \text { of } \\
\text { Respondents }\end{array}$ \\
\hline $\begin{array}{l}0-5 \\
6-10 \\
11-15 \\
16-20 \\
21-25 \\
26-30 \\
31-35 \\
\text { Over } 41\end{array}$ & $\begin{array}{r}45 \\
24 \\
18 \\
06 \\
02 \\
03 \\
+ \\
+\end{array}$ & $\begin{array}{r}0-5 \\
6-10 \\
11-15 \\
16-20 \\
21-25 \\
26-30 \\
36-40 \\
\text { Over } 41\end{array}$ & $\begin{array}{l}20 \\
28 \\
24 \\
09 \\
25 \\
06 \\
+ \\
+\end{array}$ \\
\hline
\end{tabular}

B. Administrative responsibility and primary responsibility ("jobtype") of academic library respondents.

Administrative responsibility

Top administrators (director, associated director, etc.)

$\%$ of Respondents in This Category*

Department head

Area head

No administrative responsibility

Primary responsibility ("jobtype")

Administration

Acquisitions

12

Cataloging

Serials

Outreach

Automation services

Reference/information services

Collection development

Other (special collections, etc.)

No response

*Does not equal $100 \%$ due to rounding.

tLess than $1 \%$.

mained widely dispersed in collection size. The average nonprofessional staff to professional staff ratio was five to one. Professional staff tended to have spent limited time in their present positions (nearly 50 percent had less than five years experience) and relatively few years as professionals (nearly 50 percent less than ten years). Most academic library respondents did not hold top administrative positions, but did have some clearly defined administrative responsibility. The largest group of respondents were public service librarians. The job type of respondents 
showed considerable variety.

\section{Measurement}

The studies within this project were concerned with analyzing possible relationships among these four key variables:

1. information acquisition: the degree of contact a decision maker has with different institutional, oral, and written sources of information.

2. information dissemination: the extent to which a decision maker outputs information in the form of written and oral communications to people, both in and outside of the library.

3. information evaluation: the extent to which certain types of information sources (e.g., books, reports, etc.) are used by a decision maker to make library decisions.

4. library climate: the decision maker's perception of how the library functions in the community.

Instruments used to measure each of these variables were developed by the authors and detailed information about their development and operation can be obtained elsewhere. ${ }^{25}$

Information Processing Variables. The total use of information for decision making was termed information processing and measured through the administration of three scales labeled information acquisition, information dissemination, and information evaluation. In general, information acquisition measured the decision maker's contact with different information sources. Respondents were asked to estimate the number of times they came into contact with the sources in figure 1 . Scale variables were analyzed by adding together contact times to form an overall information acquisition score that reflected the type and diversity of contacted sources.

Information dissemination gauged the extent to which respondents originated oral or written contact with other library and nonlibrary personnel. Further, it should be noted that both information dissemination and information acquisition were measured only for information sources broadly related to the organiza- tion, the job-related activities of the individual, or professional interests of the respondents.

Finally, decision makers' preferences for particular information sources were measured in the following manner. A list of ten decision situations common to libraries was constructed by the researchers in consultation with practitioners (see figure 2). These were matched with a list of potential information sources from which information could be gathered to aid in making the decision. The list was further detailed to reflect interpersonal contact, written documents, group contact, or personal investigation. Respondents were asked to indicate their first choice of an information source for resolving each decision situation by matching the source with the situation (see figure 3). Since this part of the instrument reflected categorical responses (i.e., "yes/no" type of responses), no attempt was made to construct an ordinal or interval level scale.

Climate Variables. Organizational climate can be a powerful conceptual tool for library administrators and staff to view library organization in a nontraditional way. The term refers to perceptual views held by organizational members of organizational functioning. ${ }^{26}$ Although climate as an area of organizational research has proved popular with those outside of librarianship, library researchers remain indifferent. They adhere to the traditional view of organizations as collections of hierarchical levels of authority and jobrelated roles that workers and administrators occupy, and rarely consider the "psychological" organization. ${ }^{27}$ From a psychological point of view, organizations are collections of transitory coalitions, perceptions, and values. These values lead to behavior.

Organizational climate was operationalized by constructing a library climate profile consisting of five scales, each of which had been previously tested for reliability and validity, ${ }^{28}$ and were retested to insure continued reliability and validity in this study (see below). These scales were

- innovation: the degree to which a library is ready to pursue innovative practices, 
A. Contact with Information

1. Membership on state, regional, or national professional organizations

2. Service on professional organization committees

3. Professional meetings, workshops, colloquia attended

4. Papers, speeches, discussion panels served on at professional meetings

5. Number of elected offices held in professional organizations

6. Service on library committees or advisory groups

7. In-library contact with
a. Library director of assistant/associate director
b. Professional librarian
c. Paraprofessional librarian
d. Patrons
e. Vendors
f. Others

8. Outside-library contact with
a. Professional librarians
b. Community or other nonlibrary officials
c. Vendors
d. Patrons
e. Others

9. Personal subscription to professional journals

10. Regular scanning of professional journals

11. Number of professional articles read

12. Number of professional articles published

13. Book reviews published

14. Active participation in writing of library reports

B. Dissemination of Information

1. Number of memos written on an average day to people inside library

2. Number of letters or telephone calls to people outside library

3. Initiation of job-related oral information to
a. Library director of assistant/associate director
b. Professional librarian (within organization)
c. Paraprofessionals (within organization)
d. Community or other non-library officials/administrators

\section{FIGURE 1}

List of Information Sources Contacted by, or Disseminated by, Librarians

policies, and services;

- support: the degree to which a library maintains mutually supporting relationships between different work groups within that library;

- freedom: the degree to which library staff feel co-opted by the organization in terms of that organization's rules, regulations, and "official" point of view;

- democratic governance: the extent to which library staff feel that they have the opportunity to participate in library decision making (not the degree to which they actually participate-an important distinction);

- esprit: the level of morale and shared purpose among library staff.
It is important to remember that those scales measured the participants' perception of their library climate.

After the instruments were constructed, they were pretested and edited to remove references unique to specific library type in order to use them unmodified in different library contexts. The final instrument consisted of a continuously paged document divided into three sections:

- section one asked for information about the respondent;

- section two asked for information about how the individual processed information;

- section three was the library climate profile. 
1. Automation of circulation

2. Evaluation of candidates for a new position

3. Purchasing books or other materials for the library

4. How to equitably allocate the acquisitions budget

5. How to reorganize the floor space of the library work areas and stacking areas

6. Whether the library should increase or decrease hours of operation

7. Providing online database reference service

8. Establishing or improving the library security system

9. Joining a union or collective bargaining unit

10. Joining a cooperative bibliographic network

FIGURE 2

List of Decision Situations

Internal Information Sources

A. Interpersonal communication with professional and nonprofessional staff

B. Library produced documents, reports, etc.

C. Library committees and/or groups of professionals and/or nonprofessionals

External Information Sources

D. Interpersonal communication with other professionals outside of the library

E. Interpersonal communication with users, committees, or others

Written Documents

F. Articles, book reviews, brochures, books, etc.

Personal (noninterpersonal communication)

G. Past experience and/or personal research into the nature of the problem

FIGURE 3

Categories of Informations Sources

The information processing portions required numerical answers (i.e., "how many'), while the library profile was scored 0-1 depending upon whether or not the respondent replied in a predetermined keyed direction.

\section{Quality of Data}

Reliability and validity analysis showed that the instruments used in this research were equal to results found in previous studies by the authors. ${ }^{29}$ Coefficient alphas were calculated for each interval level scale using the SPSS program RELIABILITY. ${ }^{30}$ This measure indicates the degree to which individual items in a scale "tie together" and are therefore taken from the same domain of all possible items that could be selected. In other words, coefficient alpha measures the internal consistency of a scale. ${ }^{31}$

Alpha coefficients were calculated over the total of 669 public and academic librarian responses in the study to achieve the maximum power of the tests involved by including the largest number of individual respondents. Reliability coefficients were moderate, ranging from a low of .52 (information dissemination) to a high of .72 (democratic governance). The average coefficient alpha was .65 , with the more sensitive psychologically oriented climate scales exhibiting the higher alphas and the more robust scales (i.e., those more easily quantifiable information-processing scales) the lower.

In order to assess validity beyond these methods used in previous work by the authors, scores obtained from each group of library respondents (public and academic) were subjected to factor analysis using the SPSS program FACTOR. ${ }^{32}$ If the instruments did indeed measure both information processing and organizational climate variables, then factor analysis should result in extraction of two factors; one containing high loadings on the information processing scales and the other on the climate scales. This is precisely what occurred, and table 3 shows the factor break- 
downs for the academic library data.

\section{RESULTS}

Pearson product moment correlations were the primary method of analysis used. ${ }^{33}$ Table 4 is a summary matrix of the relationships among the two information scales (information acquisition and information dissemination) and the five climate scales (democratic governance, support, esprit, freedom, innovation). As expected, information acquisition correlated highly with information dissemination. However, among the climate scales, only democratic governance correlated significantly with information dissemination.

This finding differed from the public library findings where correlations between climate scales and information scales were generally significant and posi- tive. However, as expected, the climate scales showed strong positive correlations among themselves. Democratic governance appears to be the link between the two groups of variables in contrast to the public library group where support was more significant.

\section{Evaluation of Information Sources}

The section of the instrument measuring evaluation of information sources was analyzed item by item in order to discover predominate types of information sources preferred in individual decision situations. Since the data were categorical in nature, frequency counts were used. To provide a framework for a broader review of this data's implications, each of the possible information sources was grouped into four main categories according to

TABLE 3

FACTOR ANALYSIS OF SCALES FOR ALL LIBRARIANS USING VARIMAX ROTATION $(\mathrm{N}=669)$

\begin{tabular}{lcc}
\hline \hline Scale & Factor 1 & Factor 2 \\
\hline Information acquisition & $\star$ & .87 \\
Information dissemination & $\star$ & .68 \\
Democratic governance & .81 & $\star$ \\
Support & .75 & $\star$ \\
Innovation & .60 & $\star$ \\
Freedom & .72 & $\star$ \\
Esprit & .83 & $*$ \\
\hline
\end{tabular}

*The eigenvalues (not shown) indicate that the information processing variables (information acquisition and information dissemination) account for a total of $60 \%$ of the total variance among all scales. Note that the highest loading among the information processing scales is that of "information acquisition," and among the climate scales "democratic governance'" and "esprit." An asterisk ("*") indicates a loading of less than .50 .

\section{TABLE 4}

INFORMATION PROCESSING AND CLIMATE SCALE

INTERCORRELATION MATRIX $(\mathrm{N}=356)$

\begin{tabular}{|c|c|c|c|c|c|c|c|}
\hline & $\begin{array}{l}\text { Information } \\
\text { Acquisition }\end{array}$ & $\begin{array}{l}\text { Information } \\
\text { Dissemination }\end{array}$ & $\begin{array}{l}\text { Democratic } \\
\text { Governance }\end{array}$ & Support & Innovation & Freedom & Esprit \\
\hline \multicolumn{8}{|l|}{ Information } \\
\hline Acquisition & $x$ & & & & & & \\
\hline \multicolumn{8}{|l|}{ Information } \\
\hline Dissemination & $.20^{*}$ & $x$ & & & & & \\
\hline \multicolumn{8}{|l|}{ Democratic } \\
\hline Governance & .06 & $.12 t$ & $x$ & & & & \\
\hline Support & .07 & .03 & .58 & $\mathrm{x}$ & & & \\
\hline Innovation & .03 & .07 & $.47^{\star}$ & $.37^{\star}$ & $x$ & & \\
\hline Freedom & .07 & .06 & $.67^{*}$ & $.48^{*}$ & $.51^{*}$ & $\mathrm{x}$ & \\
\hline Esprit & .04 & .02 & $.67^{\star}$ & $.66^{\star}$ & $.47^{\star}$ & $.57^{\star}$ & $x$ \\
\hline
\end{tabular}

*Significant at .01 level.

+Significant at .05 level. 
whether the source in question was likely to be found

- inside the library (internal information sources),

- outside the library (external information sources),

- in written form (written documents produced by nonlibrary sources), or

- by the information seeker's preference for independently finding sources without consultation, either through personal research or some other means (personal-noninterpersonal sources).

Information sources were grouped into subcategories and placed within each of the major four categories (see figure 3 ).

Table 5 shows results obtained from the rearrangement of the data and the frequency counts for each group of information sources. Academic library respondents in the study show an overwhelming preference for internal information sources in decision making, a finding similar to that for the public librarian group but considerably more pronounced here. It should be noted that there was a fair amount of variation in potential information sources listed under a category "other," thus accounting for some discrepancies in the table. However, the degree of variability was insufficient to negate the general pattern that emerges from examining table 5 .

Table 5 indicates that academic librarians rarely consult nonorganizational members for information on any decisionmaking situation. The category "hours of operation" (i.e. how long should we be open) is particularly striking. Interpersonal communication with library staff seems to be the predominant means by which librarians determine when to operate; users account for an insignificant percentage. In addition, librarians seem to prefer the committee structure in numerous situations (e.g. candidate evaluation). However, committees are rarely used alone and are usually listed as having nearly as much influence on the decision maker as interpersonal communication outside of a structured environment.

\section{Communication Variables}

Table 6 exhibits frequency counts of information sources selected by respondents analyzed in terms of who or what group is preferred for acquiring information and is particularly revealing. To analyze the data from this point of view, information source preferences were examined in terms of four communication-based variables compared to one written document-based variable. The communication variables were

- users, those who sought some service from the library;

- professional staff, those who were so designated as such by the library in which they worked;

- nonprofessional staff, those not desig-

TABLE 5

FREQUENCY OF PROFESSIONAL STAFF SELECTIONS

OF SPECIFIC INTERPERSONAL INFORMATION SOURCES

FOR SELECTED DECISION SITUATIONS (IN PERCENTAGES)

\begin{tabular}{|c|c|c|c|c|c|}
\hline Decision Situation & Users & $\begin{array}{l}\text { Other } \\
\text { Professional } \\
\text { Staff (in the } \\
\text { Same Library) }\end{array}$ & $\begin{array}{c}\text { Nonprofessional } \\
\text { Staff }\end{array}$ & $\begin{array}{l}\text { Professional } \\
\text { Committees }\end{array}$ & $\begin{array}{l}\text { Internal } \\
\text { Reports }\end{array}$ \\
\hline Automation of circulation & * & 21 & * & 9 & 6 \\
\hline Candidate evaluation & * & 23 & 1 & 39 & * \\
\hline Purchase of materials & 5 & 18 & * & 5 & * \\
\hline Allocating the acquisitions budget & 2 & 24 & * & 27 & 17 \\
\hline Allocating floor space & * & 21 & 4 & 37 & 5 \\
\hline Hours of operation & * & 52 & * & * & * \\
\hline Whether to begin online reference service & 4 & 25 & * & 15 & 3 \\
\hline Library security & & 13 & * & 17 & 7 \\
\hline Whether to join a union & * & 19 & * & 17 & 1 \\
\hline Whether to join network & * & 17 & * & 22 & 2 \\
\hline
\end{tabular}

${ }^{*}$ Less than $1 \%$.

NOTE: Percentages represent only those respondents selecting a specific interpersonal information source for a particular decision situation, thus columns do not total $100 \%$. 
TABLE 6

FREQUENCY OF PROFESSIONAL STAFF SELECTION

OF SPECIFIC TYPES OF INFORMATION SOURCES

IN SELECTED DECISION SITUATIONS (IN PERCENT)

\begin{tabular}{|c|c|c|c|c|c|c|c|}
\hline Decision situation & \multicolumn{3}{|c|}{ Internal } & \multicolumn{2}{|c|}{ External } & $\underset{\mathrm{F}}{\text { Written }}$ & $\begin{array}{c}\text { Personal } \\
\text { G }\end{array}$ \\
\hline Automation of circulation & & & & & 01 & & \\
\hline Candidate evaluation & 24 & * & 39 & 09 & * & 03 & 20 \\
\hline Purchase of materials & 18 & 01 & 06 & 09 & * & 52 & 10 \\
\hline Allocating the acquisitions budget & 25 & 17 & 32 & 03 & * & 08 & 11 \\
\hline Allocating floor space & 25 & 05 & 37 & * & * & 09 & 19 \\
\hline Hours of operation & 52 & * & * & * & * & * & * \\
\hline Whether to begin online reference & 25 & 03 & 16 & 13 & 08 & 20 & 07 \\
\hline Library security & 14 & 07 & 21 & 16 & * & 25 & 11 \\
\hline Whether to join a union & 19 & 01 & 20 & 09 & 06 & 11 & 27 \\
\hline Whether to join a network & 18 & 02 & 22 & 20 & 06 & 17 & 09 \\
\hline
\end{tabular}

*Less than $1 \%$.

Notes: Percentages represent only those respondents selecting a specific source for a specific decision situation, thus columns do not total $100 \%$. The types of information sources are described in figure 3 .

nated as professional and usually categorized as paraprofessional;

- professional committees, those professionals who deliberately established a structure within which decisions would be made;

- internal reports, materials produced within the library from data collected by library personnel.

As suggested in table 6, academic librarians in this study have little interest in user input to library decision making. In only three instances, purchase of material, allocating the acquisitions budget, and whether to begin online reference service, was the user to be consulted at all. As was expected, librarians preferred interpersonal contact with their peers either separately or within a committee structure. Further, nonprofessional staff do not form a part of the professional librarian's decision-making environment.

Potential information sources as input for decision making such as continuing education, past experience, personal opinion, and conducting research were not identified as important to decision making. Thus, findings would suggest that democratic governance appears to be the climate dimension most closely associated with information dissemination, that academic librarians tend to select internal oral information sources as input for decision making, and that there is little dependence on user information or information based on organizational research as input for decision making.

\section{Information Processing Variables}

In addition to examining the relationships between climate and information processing variables, the individual items that made up the scales information acquisition and information dissemination were closely examined. The information acquisition and dissemination scales were composed of a list of potential information sources. Librarians were asked to indicate the frequency with which they came into contact with, or initiated output of, these information sources (see figure 1).

Table 7(a) demonstrates the types of information contact patterns that are likely to emerge in academic libraries and represents a "map" of which information sources are seen as important. For example, note the significant correlation between librarian professional meetings attended and library administration. Such a relationship may indicate the relative isolation of many academic librarians from their administration who may have such exposure to professional organization information sources.

Table 7(b) shows correlations among information dissemination methods. These suggest that written communication is a popular means of distributing information across hierarchical lines and that while many verbal communications links exist, 
TABLE 7

CORRELATION MATRICES

A. Correlation Matrix Showing Academic Librarian Information Acquisition Related to Professional Activity

\begin{tabular}{|c|c|c|c|c|c|}
\hline & $\begin{array}{l}\text { Membership } \\
\text { in Prof. } \\
\text { Organizations }\end{array}$ & $\begin{array}{l}\text { Membership } \\
\text { in Prof. } \\
\text { Committees }\end{array}$ & $\begin{array}{c}\text { Librarian Professional Activity } \\
\text { Prof. } \\
\text { Meetings } \\
\text { Attended }\end{array}$ & $\begin{array}{c}\text { Prof. } \\
\text { Projects } \\
\text { Undertaken }\end{array}$ & $\begin{array}{l}\text { Prof. } \\
\text { Offices } \\
\text { Held }\end{array}$ \\
\hline $\begin{array}{l}\text { Librarians' } \\
\text { Contact with . . . } \\
\text { Library administration } \\
\text { Professionals } \\
\text { Paraprofessionals } \\
\text { Patrons } \\
\text { Vendors } \\
\text { Others } \\
\text { Librarians outside library } \\
\text { Community officials outside library } \\
\text { Vendors outside library } \\
\text { Users outside library } \\
\text { Others outside library }\end{array}$ & $\begin{array}{c}.03 \\
.05 \\
-.03 \\
.00 \\
.09 \\
-.03 \\
.09 \\
.15^{\star} \\
.06 \\
.09 \\
.01\end{array}$ & $\begin{array}{c}.27^{\star} \\
.03 \\
-.06 \\
.00 \\
.08 \\
-.02 \\
.01 \\
.16^{\star} \\
.14^{\star} \\
.11 \dagger \\
-.03\end{array}$ & $\begin{array}{c}.22^{\star} \\
-.04 \\
.09 \\
.03 \\
.17^{\star} \\
-.04 \\
.13^{\star} \\
.07 \\
.03 \\
-.03 \\
.00\end{array}$ & $\begin{array}{c}.27^{\star} \\
.05 \\
.04 \\
-.03 \\
.23^{\star} \\
.03 \\
.18^{\star} \\
.17^{\star} \\
.16^{\star} \\
.10 \\
-.04\end{array}$ & $\begin{array}{r}.01 \\
.22 \\
-.01 \\
.06 \\
.01 \\
-.01 \\
.01 \\
.06 \\
.07 \\
.07 \\
.01\end{array}$ \\
\hline
\end{tabular}

B. Correlation Matrix of Information Dissemination Methods

\begin{tabular}{|c|c|c|c|c|c|c|c|}
\hline & \multirow[b]{2}{*}{ Memos } & \multicolumn{3}{|c|}{ Information Output } & \multirow[b]{2}{*}{$\begin{array}{l}\text { Verbal } \\
\text { Comm. } \\
\text { with } \\
\text { Para- } \\
\text { Prof. }\end{array}$} & \multirow[b]{2}{*}{$\begin{array}{l}\text { Verbal } \\
\text { Comm. } \\
\text { with } \\
\text { Community } \\
\text { Officials }\end{array}$} & \multirow[b]{2}{*}{$\begin{array}{l}\text { Verbal } \\
\text { Comm. } \\
\text { with } \\
\text { Others }\end{array}$} \\
\hline & & Letters & $\begin{array}{l}\text { Verbal } \\
\text { Communication } \\
\text { with the } \\
\text { Administrators }\end{array}$ & $\begin{array}{c}\text { Verbal } \\
\begin{array}{c}\text { Communication } \\
\text { with }\end{array} \\
\text { Professionals }\end{array}$ & & & \\
\hline Memos & $x$ & & & & & & \\
\hline Letters & $.32^{\star}$ & & & & & & \\
\hline Verbal communication with top administration & $.14 t$ & $.32^{\star}$ & $x$ & & & & \\
\hline Verbal communication with professionals & $.17^{\star}$ & .09 & $.19+$ & $x$ & & & \\
\hline Verbal communication with paraprofessionals & $.11^{\star}$ & $.20+$ & $.13+$ & $.42^{*}$ & $x$ & & \\
\hline Verbal communication with community officials & $.18 t$ & $.30 t$ & $.19+$ & $.37 t$ & .30 & $x$ & \\
\hline Verbal communication with others & .03 & .02 & -.01 & .03 & -.01 & .07 & $x$ \\
\hline
\end{tabular}

* Significant at .01 level.

tSignificant at .05 level. 
they may be used for transmitting relatively insignificant information. Although it is possible that written documents simplify information flow, they may also reduce the amount of decision-making information transmitted, increase the perceived distance between administration and staff, and strengthen the bureaucratic nature and class structure of academic libraries.

Finally, table 8 is a "snapshot" of all 669 academic and public librarians in the study. It shows connections between ways in which librarians initiate contact, and acquire information. The correlations between such variables as "initiating contact with administrators" and "contact with administrators" may suggest that there are forces at work which impede information flow and quality decision making, such as coalition formation and between-group isolation. It is surprising to note that regardless of the communication preferences, there is little contact with patrons.

Two conclusions can be reached from the data in table 8. First, although communication links are strong, professional librarians report little contact, and in no case statistically significant contact, with paraprofessional staff. Paraprofessionals seem to be ignored as meaningful sources of "professional" decision-making information. Second, it is possible that in many librarians' minds the well-informed librarian (information rich) is one who is in contact with documents and other written sources, in communication with other groups in the library, and professional organizations but not with patrons. Those who have worked in an academic library for any length of time will recognize this phenomenon. It is a very common situation wherein the various groups on a campus will tend to gravitate to particular librarians for information whether or not the librarian may be qualified to provide such information.

\section{DISCUSSION}

The findings presented in this paper suggest that the decision-making process in academic libraries may be shortcircuited and that in terms of exploiting a

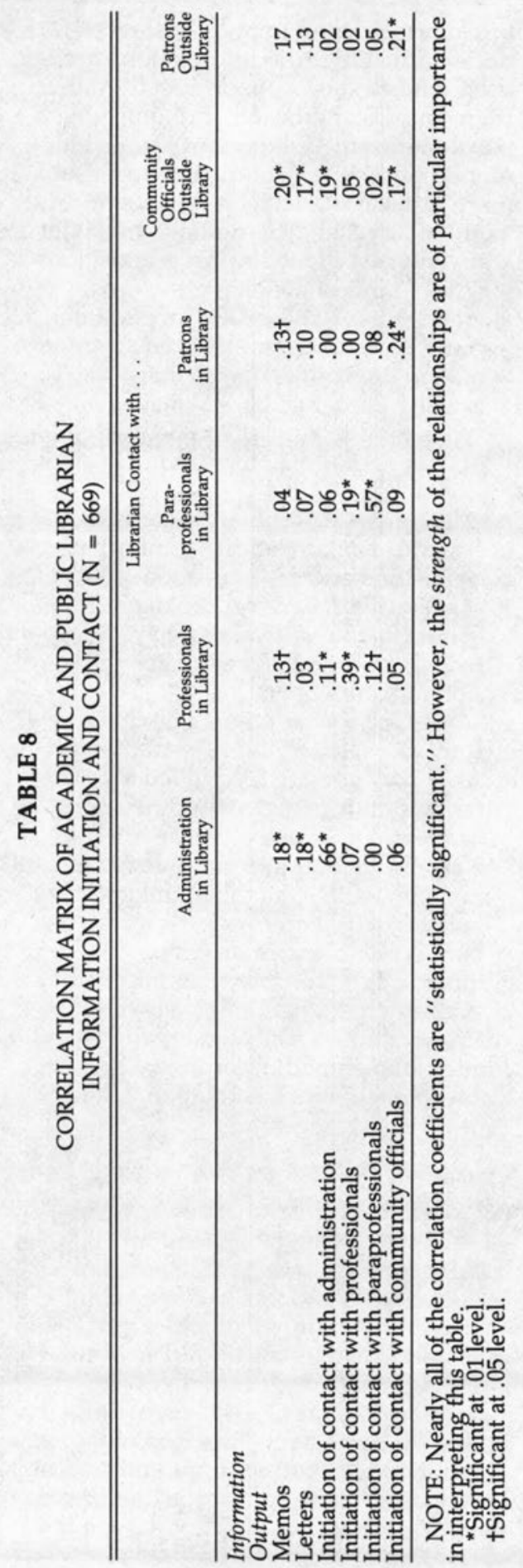


broad array of information resources for decision making, the information that is used tends to be "opinion-based" rather than empirically based. Proximity also plays an extremely important part in information source selection: the closer and more familiar a source is, the more it is likely to be used. The findings from this study suggest the following propositions for further investigation:

- management styles that stress democratic governance are related to information dissemination activities;

- existing academic library management styles tend to restrict contact with and dissemination of information for decision making;

- existing academic library organizational structures retard effective information acquisition and dissemination;

- academic librarians ignore many types of information sources that have the potential to improve the quality of decision making;

- academic libraries can best be characterized as "closed" administration systems that provide for limited information input from the environment;

- academic libraries have developed a class conscious information environment in which status and familiarity determine what information sources will be used for decision making.

Support for such propositions implies that overall, there is little emphasis on information resources management (IRM) and limited understanding on how access to and exploitation of information is related to the decision-making process.

\section{Selection of Information Sources for Decision Making}

The effectiveness of the decisionmaking process is highly dependent on the acquisition and dissemination of information. While numerous other variables will affect the degree to which decision making is effective, e.g., politics, individual competencies, and management styles-to name a few, the importance of obtaining a relevant, accurate, and current information base cannot be underestimated.

The lack of emphasis on user-based or sion making is especially worrisome as it reinforces the "closed" nature of academic library decision making. Implications of minimal input from academic library clientele include

- limited needs assessment and evaluation of the degree to which information services are, in fact, meeting clientele information needs;

- maintenance of existing services and activities on the assumption that they do, in fact, meet clientele information needs;

- limited development of information programs and services, and emphasis on collection building and bibliographic control;

- inability to respond quickly and effectively to changing environmental conditions, e.g., curriculum changes, revised institutional missions, use of personal microcomputers, etc.

In short, current academic library decision-making processes encourage ineffective activities since they preclude or limit clientele input, empirical research, and additional environmental input.

The heavy reliance of academic librarians on internal oral sources for decision making encourages information nepotism, or the propensity of librarians to seek the same few types of information sources and use them as input for a broad array of decision situations. Findings reported from studying the way in which librarians accumulate and disseminate information support this conclusion and simply reinforce the "law of least effort" that, when applied to information for decision making, suggests that the individual will select an information source of reduced relevance, accuracy, and timeliness simply because it is easily accessible. ${ }^{34}$ Information nepotism discourages a search for alternative information sources, the evaluation of sources selected, and provides a false sense of security that "adequate" information has, in fact, been obtained as input to the decision-making process.

The limited reliance on empirical data and original research-either at an organizational or individual level of production-is also of concern. Explanations for this finding include the possibility that, although a sample of academic 
and research library directors rated "research skills" as highly desirable for beginning academic librarians, ${ }^{35}$ few academic librarians have had adequate training in how to conduct research and how research can be integrated into library operations. Moreover, those younger librarians most likely to have had some exposure to the research process appear to be least likely to be involved in decision making.

In addition, the vast majority of academic libraries have no formal mechanisms or systems by which information is collected, organized, and analyzed specifically for a management information system or a decision support system. Clearly, the development of systems for the management of information are sorely needed in all libraries. But by and large, (as the findings from this study suggest) decision making continues to be based on "informed opinion" and usually that opinion is from someone already in the organization. Until academic libraries construct such decision support systems, there will continue to be an implied encouragement to rely on oral internal sources since little else is immediately available.

A conscious attempt to develop inhouse decision support systems for library decision making is essential and strategies have been suggested by which this can be accomplished. ${ }^{36}$ However, a significant change is necessary in the attitude of most academic librarians to recognize the importance of information, the need for a broad base of information input, and the desire to utilize such information for decision making before adequate resources are likely to be committed to the development and operation of such systems.

\section{Information Acquisition and Organizational Climate}

The effectiveness with which decisions are made in organizations and how information is used in such decision making is particularly prone to psychological perceptions as measured by the various climate scales. An "information rich" organization can only be created by setting conditions that enhance information acquisition and dissemination, that train li- brary staff (all library staff-not just the professionals) on techniques for effectively using information for decision making, and regularly assessing the effectiveness with which information is, in fact, integrated into traditional administrative activities such as decision making, planning, budgeting, etc. Apparently, it is the information rich organization that encourages change from "closed" inflexible environments to "open" innovative organizations.

The problem of attitudes is related to the various psychological perceptions of the organization by staff members, many of which can be measured by the climate dimensions suggested earlier in this paper. Knowledge of existing climate conditions and the degree to which those climates are desirable for a particular library setting are essential if strategies are to be developed by library administrators to move the organization from one management style to another.

If a conscious decision has been made that the library should modify a specific dimension of either information processing or organizational climate, the findings from this study suggest that dimensions of each of these can, in fact, be measured and monitored over time. However, such actions assume that library administrators consciously consider the management style that they currently employ and can specify the elements of either information processing or organizational climate that they wish to increase or decrease. In short, significant opportunities are present for those library administrators who wish to analyze their existing information processing and climate conditions.

\section{Information Management Strategies}

A number of intervention strategies can be taken to improve the quality of decision making. First, organizational assessment of what information sources are currently used for decision making is needed. Second, academic librarians can obtain training in information resources management, evaluation of information sources for decision making and broadening their sources as input for decision making. Third, mechanisms can be established to 
encourage input from clientele and empirical research for decision making. Fourth, academic library administrators should consider the development of various types of management styles to encourage increased access to and utilization of information for decision making. And finally, greater attention is needed for the development of management information systems and decision support systems in academic libraries.

The next step for research in this area is relating information processing and organizational climates to measures of productivity and effectiveness. For example, under what organizational conditions can information processing skills contribute to increased productivity or under what organizational conditions can organizational climates contribute to increased productivity? An underlying assumption for most models of decision making is a relationship between information process- ing skills and increased organizational effectiveness. But the specific nature of this relationship and the effect of various types of organizational climates on overall library effectiveness or productivity are not clear.

What is clear, however, is the need for academic library administrators to carefully assess existing skills related to information processing; to assess the degree to which individuals have relevant, accurate, and up-to-date information as a basis for daily decision making and long-range planning; and the ability of the organization to provide formal mechanisms by which information can be managed for increased overall organizational effectiveness. Such assessment is essential if academic libraries are to be able to respond to a rapidly changing environment, meet and resolve clientele information needs, and obtain full productivity from library staff members.

\section{REFERENCES}

1. Alan R. Samuels and Charles R. McClure, "Toward a Theory of Library Administration," in Strategies for Library Administration: Concepts and Approaches, eds. Charles R. McClure and Alan R. Samuels (Littleton, Colo.: Libraries Unlimited, 1982), p. 12-28.

2. Lyman W. Porter and Karlene H. Roberts, "Communication in Organizations," in Handbook of Industrial and Organizational Psychology, ed. M. D. Dunnette (Chicago: Rand McNally, 1976), p. 1553-89.

3. Arthur P. Brief and H. Kirk Downey, "Cognitive and Organizational Structures: A Conceptual Analysis of Implicit Organizing Theories," Human Relations 36:1065-90 (Dec. 1983).

4. Charles R. McClure, Information for Academic Library Decision Making (Westport, Conn.: Greenwood, 1980); Charles A. O'Reilly III, 'Variations in Decision Makers' Use of Information Sources," Academy of Management Journal 25:756-71 (Dec. 1982); Norman D. Stevens, Communication Throughout Libraries (Metuchen, N.J.: Scarecrow, 1983).

5. Gerald M. Goldhaber and others, Information Strategies: New Pathways to Corporate Power (Englewood Cliffs, N.J.: Prentice-Hall, 1979).

6. William R. Synnott and William H. Gruber, Information Resource Management (New York: Wiley, 1981); Edward G. Summers, Joyce Matheson and Robert Conroy, "The Effect of Personal, Professional and Psychological Attributes, and Information Seeking Behavior on the Use of Information Sources by Educators," Journal of the American Society for Information Science 34:75-83 (Jan. 1983).

7. Charles A. O'Reilly III and Louis R. Pondy, "Organizational Communication," in Organizational Behavior, ed., S. Kerr (Columbus, Ohio: Grid Pub., 1978), p. 119-50.

8. I. T. Mitroff, "Archetypal Social Systems Analysis: On the Deeper Structure of Human Systems," Academy of Management Review, 8:387-97 (July 1983).

9. Alan R. Samuels, "Assessing Organizational Climate in Public Libraries," Library Research 1: 237-54 (1979).

10. Alan R. Samuels and Charles R. McClure, "Information Processing and Library Climate in Academic and Public Libraries," Public Libraries 21:66-68 (Summer 1982).

11. Miluse Soudek, "Organizational Climate and Professional Behavior of Academic Librarians," Journal of Academic Librarianship 8:334-38 (Jan. 1983).

12. R. Tagiuri and G. H. Litwin, Organizational Climate: Explorations of a Concept (Boston: Div. of Research, Graduate School of Business Administration, Harvard Univ., 1968). 
13. R. M. Guion, "A Note on Organizational Climate," Organizational Behavior and Human Performance 9:120-25 (Feb. 1973).

14. A. W. Halpin and D. G. Croft, The Organizational Climate of Schools (Bethesda, Md.: ERIC Document Reproduction Service, ED 002897,1962$).$

15. G. H. Litwin and R. A. Stringer, Motivation and Organizational Climate (Boston: Division of Research, Graduate School of Business Administration, Harvard Univ., 1968).

16. J. A. Langdale. "Assessment of Work Climates: The Appropriateness of Classical Management Theory and Humanistic Theory Under Various Contingencies" (Ph.D. diss., New York Univ., 1974).

17. Marjorie A. Stellingwerf, "A Study of the Relationship Between Public Librarians' Perceptions of Organizational Climate as Measured by the Medified IFI, and Their Ability to Estimate User Needs" (Ph.D. diss., Rutgers Univ., 1981).

18. Gerald Zaltman and Robert Duncan, Strategies for Planned Change (New York: Wiley, 1977).

19. Charles R. McClure, "Management Information for Library Decision Making," in Advances in Librarianship, v.13 ed. Wesley Simonton (New York: Academic, 1984), p.1-47.

20. Alan R. Samuels and Charles R. McClure, "Utilization of Information for Decision Making Under Varying Organizational Climate Conditions in Public Libraries," Journal of Library Administration 4:1-20 (1983).

21. Mary Lee Bundy, "Decision Making in Libraries," Illinois Libraries 43:780-93 (Dec. 1961).

22. Irving L. Janis and Leon Mann, Decision Making: A Psychological Analysis of Conflict, Choice, and Commitment (New York: Free Pr., 1979).

23. Maurice P. Marchant, Participative Management in Academic Libraries (Westport, Conn.: Greenwood, 1976); Louis Kaplan, "On Decision Sharing in Libraries: How Much Do We Know?" College \& Research Libraries 38:25-31 (Jan. 1977); McClure, Information for Academic Library Decision Making.

24. Samuels and McClure, "Utilization of Information for Decision Making."

25. Ibid., McClure, Information for Academic Library Decision Making.

26. Howard S. Schwartz, "Maslow and the Hierarchical Enactment of Organizational Reality," $\mathrm{Hu}$ man Relations 36:933-56; (Oct. 1983); Martha Feldman and James G. March, "'Information in Organizations as Signs and Symbol," Administrative Science Quarterly 26:171-86 (June 1981).

27. Alan R. Samuels, "Organizational Climate and Library Change," in Strategies for Library Administration: Concepts and Approaches eds. Charles R. McClure and Alan R. Samuels, (Littleton, Colo.: Libraries Unlimited, 1982), p. 421-31.

28. Ibid., p. 427.

29. Samuels and McClure, "Utilization of Information for Decision Making."

30. SPSS Update 7-9: New Procedures and Facilities for Release 7-9 (New York: McGraw-Hill, 1981), p. 248-67.

31. Richard A. Zeller and Edward G. Carmines, Measurement in the Social Sciences (New York: Cambridge Univ. Pr., 1980), p.58.

32. SPSS: Statistical Package for the Social Sciences, 2d ed. (New York: McGraw-Hill, 1975), p. 468-514.

33. Ibid., p. 280-292.

34. P. G. Gerstberger and T. J. Allen, "Criteria Used by Research and Development Engineers in the Selection of an Information Source," Journal of Applied Psychology 52:272-79 (Aug. 1968).

35. Maurice P. Marchant and Nathan M. Smith, "The Research Library Director's View of Library Education," College and Research Libraries 43:437-44 (November, 1982).

36. M. R. Bommer and R. W. Chorba, Decision Making for Library Management (White Plains, N.Y.: Knowledge Industry Publ., 1982); McClure, "Management Information for Library Decision Making." 